University of Nebraska - Lincoln

DigitalCommons@University of Nebraska - Lincoln

Nebraska Beef Cattle Reports

Animal Science Department

January 2007

\title{
Utilization of Dried Distillers Grains for Developing Beef Heifers
}

Jeremy L. Martin

University of Nebraska-Lincoln

Andrea S. Cupp

University of Nebraska-Lincoln, acupp2@unl.edu

Richard J. Rasby

University of Nebraska-Lincoln, rrasby1@unl.edu

Karl V. Moline

University of Nebraska-Lincoln, kmoline1@unl.edu

Jeffrey W. Bergman

University of Nebraska-Lincoln, jbergman1@unl.edu

See next page for additional authors

Follow this and additional works at: https://digitalcommons.unl.edu/animalscinbcr

Part of the Animal Sciences Commons

Martin, Jeremy L.; Cupp, Andrea S.; Rasby, Richard J.; Moline, Karl V.; Bergman, Jeffrey W.; Dragastin, Mark; and Funston, Richard N., "Utilization of Dried Distillers Grains for Developing Beef Heifers" (2007). Nebraska Beef Cattle Reports. 56.

https://digitalcommons.unl.edu/animalscinbcr/56

This Article is brought to you for free and open access by the Animal Science Department at DigitalCommons@University of Nebraska - Lincoln. It has been accepted for inclusion in Nebraska Beef Cattle Reports by an authorized administrator of DigitalCommons@University of Nebraska - Lincoln. 
Authors

Jeremy L. Martin, Andrea S. Cupp, Richard J. Rasby, Karl V. Moline, Jeffrey W. Bergman, Mark Dragastin, and Richard N. Funston

This article is available at DigitalCommons@University of Nebraska - Lincoln: https://digitalcommons.unl.edu/ animalscinbcr/56 


\section{Utilization of Dried Distillers Grains for Developing Beef Heifers}

\author{
Jeremy L. Martin \\ Andrea S. Cupp \\ Rick J. Rasby \\ Karl V. Moline \\ Jeff W. Bergman \\ Mark Dragastin \\ Rick N. Funston ${ }^{1}$
}

\section{Summary}

A two-year study evaluated feeding dried distillers grains (DDG) during heifer development on growth and reproductive performance. Supplements provided similar $C P$, energy, lipid, and fatty acids. Protein degradability of the supplements differed such that undegradable intake protein exceeded requirements of DDG heifers. Heifer pubertal development, artificial insemination (AI) pregnancy rate, and overall pregnancy rate were not affected by supplement. However, AI conception rate and AI pregnancy rate were improved by feeding $D D G$ in the heifer development diet.

\section{Introduction}

The majority of replacement heifers developed in Nebraska are supplemented with protein and energy. In forage-based diets, dried distillers grains (DDG) have greater energy value than corn and are nearly $30 \% \mathrm{CP}$, with greater than $50 \%$ of the $\mathrm{CP}$ in the form of undegradable intake protein (UIP). Therefore, DDG may be an economically feasible source of energy and protein for growing replacement heifers.

When DDG are fed as an energy source in growing heifer diets, UIP is supplied in excess of requirements. Supplementation of prepubertal heifers with $250 \mathrm{~g} / \mathrm{d}$ excess UIP increased age at puberty compared to heifers fed monensin and increased weight at puberty compared to control heifers (Lalman et al., 1993 Journal of Animal Science 71:2843). In the same study, fewer UIP supplemented heifers were detected in estrus during the first 21 days of the breeding season, but pregnancy rates were similar. Additionally, supplementing postpubertal heifers with high UIP decreased serum concentrations of follicle stimulating hormone, a key hormone in reproduction (Kane et al., 2004 Journal of Animal Science 82:283). Research is needed to determine if supplementing heifers with excess UIP from DDG affects development or reproduction.

\section{Procedure}

All procedures were approved by the University of Nebraska Institutional Animal Care and Use Committee. Weaned heifer calves $(\mathrm{n}=316)$ were blocked by age at location one (University of Nebraska Dalbey-Halleck farm, Virginia, Neb.) and age by sire at location two (University of Nebraska Agricultural Research and Development Center, Ithaca, Neb.) and assigned randomly within block to receive DDG or control (CON) supplement during development. Heifers from location one were composite MARC II ( $1 / 4$ Hereford, $1 / 4$ Angus, $1 / 4$ Simmental, $1 / 4$ Gelbvieh), Angus ${ }^{\star}$ Simmental, and Angus ${ }^{\star}$ Gelbvieh genetics. At location two, composite MARC III (1/4 Angus, 1/4 Hereford, 1/4 Red Poll, 1/4 Pinzgauer), and MARC III ${ }^{\star}$ Red Angus heifers were utilized. Heifers were weaned at an average age of 205 days and supplementation began at an average age of 238 days. Initial and final weights and body condition scores (BCS) were taken on two consecutive days. Two blood samples were taken at 10-day intervals to determine pubertal status of heifers before the beginning of the trial. Interim weights and blood samples were collected every 14 days. Plasma progesterone was determined by radioimmunoassay. Progesterone concentration greater than $1 \mathrm{ng} / \mathrm{mL}$ in plasma was interpreted to indicate ovarian luteal activity, and thus attainment of puberty.

Supplement composition, daily intake, and protein balance are presented in Table 1. Supplementation rate was determined by body weight so that supplemental CP, energy, and lipid intake were similar between groups. An ADG of $1.5 \mathrm{lb} /$ day was targeted to achieve approximately $60 \%$ of mature weight at the time of breeding. Protein degradability of the supplements differed such that UIP was fed in excess of requirements for DDG heifers.
Additionally, lipid in both supplements was derived from corn oil so fatty acid intake was similar between treatments. To ensure consistent nutrient delivery, supplements were bagged in approximately $50 \mathrm{lb}$ bags. Supplements were fed daily in bunks with abundant bunk space. Supplement intake was adjusted to $0.73 \%$ of body weight for $\mathrm{CON}$ and $0.57 \%$ of body weight for DDG heifers following each weigh date. Each group was fed their respective supplement through the last day of AI, at which time heifers were placed in a single group on pasture.

Estrus was synchronized using two injections of prostaglandin $\mathrm{F}_{2 \alpha}$ (PGF) administered 14 days apart with an 18 gauge, 1.5 inch needle. No progestin was used for estrus synchronization to avoid hastening pubertal development. Estrus detection was performed for 5 days following the second PGF injection, and heifers observed in estrus were artificially inseminated approximately 12 hours later. Heifers were exposed to fertile bulls for approximately 45 days, beginning 10 days after the final artificial insemination (AI). Conception rate to AI was determined via transrectal ultrasonography approximately 45 days after AI. An additional ultrasound pregnancy diagnosis was performed 45 days following removal of bulls to determine final pregnancy rate.

Data included in the current report include growth performance, estrous synchronization, puberty data, and AI conception and pregnancy rates for heifers from both locations over two years. Overall pregnancy rate and final pregnancy diagnosis weight and BCS are from year one only.

Performance data were analyzed using PROC MIXED of SAS. Percentage of heifers reaching puberty, estrous synchronization response, conception rate, and pregnancy rate were analyzed using Chi-square procedures in PROC GENMOD of SAS. The model included treatment and location. The interaction between treatment and location was included for data sets when significant. In multiyear analyses, year was included as a random variable.

(Continued on next page) 
Table 1. Supplement composition (DM basis) and daily intake.

\begin{tabular}{lcc}
\hline Item & $\mathrm{CON}^{\mathrm{a}}$ & $\mathrm{DDG}^{\mathrm{b}}$ \\
\hline Ingredient \%, DM basis & & \\
Dried distillers grains & 73.00 & 99.76 \\
Dried corn gluten feed & 24.48 & \\
Whole corn germ & 2.33 & \\
Urea & 0.16 & 0.20 \\
Trace mineral premix & 0.03 & 0.04 \\
Vitamin ADE premix & 0.73 & 0.57 \\
& 92 & 253 \\
Daily supplement rate, \% of body wt & 111 & 351 \\
Maximum daily UIP intake, g/dayd & 34 & 163 \\
Metabolizable protein balance, g/day & 140 & -50 \\
Degradable intake protein balance, g/day & & \\
\hline
\end{tabular}

aSupplemented daily with control supplement $0.73 \%$ of body weight.

bSupplemented daily with dried distillers grains supplement $0.57 \%$ of body weight.

cPredicted metabolizable protein and degradable intake protein balances calculated using 1996 NRC

Level 1, predictions based on actual ADG, mid-test weight and forage value from yr 1.

${ }^{\mathrm{d}}$ Daily UIP intake averaged across the length of the experiment.

${ }^{\mathrm{D}}$ Maximum UIP intake achieved at the conclusion of the experiment.

Table 2. Effects of dried distillers grains supplementation during development on growth performance of composite beef heifers ${ }^{\text {ab }}$.

\begin{tabular}{|c|c|c|c|c|}
\hline \multirow[b]{2}{*}{ Item } & \multicolumn{2}{|c|}{ Location One } & \multicolumn{2}{|c|}{ Location Two } \\
\hline & $\mathrm{CON}^{\mathrm{c}}$ & $\mathrm{DDG}^{\mathrm{d}}$ & $\mathrm{CON}^{\mathrm{c}}$ & $\mathrm{DDG}^{\mathrm{d}}$ \\
\hline Beginning age, day & 242 & 242 & 229 & 230 \\
\hline Initial wt, $\mathrm{lb}$ & 559 & 558 & 552 & 551 \\
\hline Initial BCS & 5.33 & 5.34 & 5.38 & 5.37 \\
\hline Final wt, lb & $826^{\mathrm{ef}}$ & $820^{\mathrm{e}}$ & $804^{\mathrm{e}}$ & $845^{\mathrm{f}}$ \\
\hline Final BCS & 5.65 & 5.70 & 5.60 & 5.68 \\
\hline $\mathrm{ADG}$ & $1.45^{\mathrm{e}}$ & $1.42^{\mathrm{ef}}$ & $1.35^{\mathrm{f}}$ & $1.58^{\mathrm{g}}$ \\
\hline Final pregnancy determination wt, lb & 901 & 890 & 975 & 988 \\
\hline Final pregnancy determination BCS & 5.53 & 5.47 & 5.84 & 5.85 \\
\hline
\end{tabular}

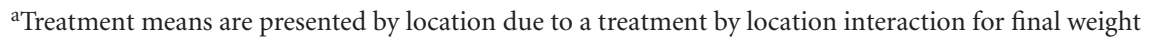
and ADG.

${ }^{\mathrm{b}}$ Includes data from year one and two, except pregnancy determination weight and BCS are from year one only.

'Supplemented daily with control supplement $0.73 \%$ of body weight.

dSupplemented daily with dried distillers grains supplement $0.57 \%$ of body weight.

efgWithin a row, means without common superscripts differ at $P<0.05$.

Table 3. Effects of dried distillers grains supplementation during development on pubertal development, estrous synchronization response, and reproductive performance of composite beef heifers ${ }^{\text {ab }}$.

\begin{tabular}{|c|c|c|c|c|}
\hline Item & $\mathrm{CON}^{\mathrm{c}}$ & $\mathrm{DDG}^{\mathrm{d}}$ & SEM & $P$-value \\
\hline Pubertal prior to PGF, $\%{ }^{\mathrm{e}}$ & 77.7 & 86.1 & 1.3 & 0.44 \\
\hline Age at puberty, day & 332 & 340 & 6 & 0.23 \\
\hline Weight at puberty, lb & 677 & 704 & 11 & 0.03 \\
\hline Estrus response, $\% \mathrm{f}$ & 75.8 & 75.9 & 4.1 & 0.98 \\
\hline Time of estrus, hours & 68.0 & 64.8 & 2.1 & 0.19 \\
\hline AI conception rate $\mathrm{h}^{\mathrm{h}}, \%$ & 52.9 & 75.0 & 6.3 & 0.0004 \\
\hline AI pregnancy rate,$\%$ & 40.1 & 57.0 & 4.0 & 0.003 \\
\hline Overall pregnancy rate, $\%$ & 89.3 & 89.4 & 3.2 & 0.97 \\
\hline
\end{tabular}

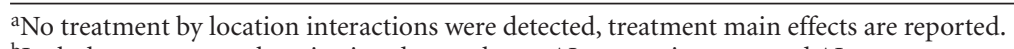

${ }^{b}$ Includes estrous synchronization data, puberty, AI conception rate, and AI pregnancy rates from both years and overall pregnancy rate from year one only.

'Supplemented daily with control supplement $0.73 \%$ of body weight.

dSupplemented daily with dried distillers grains supplement $0.57 \%$ of body weight.

ePercentage of heifers that had attained puberty prior to initial PGF injection.

fPercentage of heifers detected in estrus within $5 \mathrm{~d}$ following second PGF injection.

gTime elapsed between second PGF injection and observed standing estrus.

hProportion of heifers detected in estrus that conceived to AI service.

iPercentage of total group of heifers that conceived to AI service.
Results

Heifer performance and body condition data are presented in Table 2. There was no difference between groups $(P>0.05)$ in age, initial weight, initial BCS, or final BCS. Furthermore, weight and BCS at final pregnancy determination were not influenced $(P>0.05)$ by supplementation. There was a treatment by location interaction for final weight and ADG. Final weights and ADG were similar between groups at location one $(P>0.05)$ but were greater $(P<0.05)$ for DDG heifers than CON heifers at location two.

Supplement type did not influence $(P>0.05)$ the proportion of heifers that had achieved puberty prior to synchronization, or the average age at puberty (Table 3 ). Weight at puberty was greater $(P=0.03)$ for DDG heifers than CON heifers, primarily due to the higher ADG and final weight of DDG heifers at location two. A similar percentage $(P>0.05)$ of heifers from $\mathrm{CON}$ and DDG were detected in estrus within 5 days following the final PGF injection, and the timing of observed estrus was similar $(P>0.05)$ between groups. Conception rate to AI was greater $(P=0.0004)$ for DDG than CON heifers (52.9\% vs. $75.0 \%)$. Furthermore, AI pregnancy rates were greater $(P=0.003)$ for DDG heifers than control heifers ( $40.1 \%$ vs. $57.0 \%)$. Overall pregnancy rates following exposure to bulls were similar $(P>0.05)$ between DDG and CON heifers in year one.

\section{Conclusions}

As ethanol production in Nebraska and the Great Plains expands, greater opportunity will exist to incorporate DDG in replacement heifer diets. These data indicate that utilizing DDG as a source of protein and energy in heifer development diets to promote moderate gains enhances AI conception and pregnancy rates.

${ }^{1}$ Jeremy Martin, graduate student; Andrea Cupp, associate professor; and Rick Rasby, professor, Animal Science, Lincoln. Karl V. Moline, Cow/Calf unit manager; and Jeff Bergman, Cow/Calf unit research technician, Mead. Mark Dragastin, Dalbey-Halleck unit manager, Virginia. Rick Funston, assistant professor, Animal Science, West Central Research and Extension Center, North Platte. 